\title{
SHADE EFFECT ON GROWTH, YIELD, AND SHADE TOLERANCE OF THREE PEANUT CULTIVARS
}

\section{PENGARUH NAUNGAN TERHADAP PERTUMBUHAN, HASIL, DAN TOLERANSI NAUNGAN PADA TIGA KULTIVAR KACANG TANAH}

\author{
Noertjahyani, Choerul Akbar, Ai Komariah and Hudaya Mulyana \\ Agriculture Faculty, Universitas Winaya Mukti \\ Jl. Raya Bandung Sumedang Km 29 Tanjungsari, Sumedang \\ Corresponding email: noertjahyani@yahoo.com
}

Accepted: 30 October 2019 / Agreed: 14 July 2020

\begin{abstract}
Peanut, which is commonly planted in interculture and intercropping system, often suffers from shading caused by associated plants. This experiment aimed to study the effect of different shade levels of three peanut cultivars on the growth and seed yield, also to determine the shade-tolerant cultivar. A pot experiment was done at the Research Station of Agriculture Faculty Universitas Winaya Mukti since July until October 2016 by creating 50\%, $65 \%$, and $75 \%$ artificial shade levels during the lifetime of Tuban, Jepara, and Bima cultivars. The shade significantly affected on number of trifoliate leaves, number of branches, plant dry weight, yield components (number of pods, number of filled pods, and number of seeds), dry weight of pod, and seed weight per plant. The cultivar gave same effect on the growth and seed yield per plant. Based on Stress Tolerance Index (STI) analysis on the seed dry weight per plant, only Tuban cultivar showed great tolerance of $65 \%$ shade of natural light. Overall, the whole cutivars tested were sensitive on $75 \%$ shade level.
\end{abstract}

Keywords: peanut cultivars, shade effect, shade tolerance.

\section{ABSTRAK}

Kacang tanah yang biasa ditanam pada sistem tumpangsari dan interkultur, sering ternaungi karena berasosiasi dengan tanaman lainnya. Penelitian ini bertujuan untuk mengkaji pengaruh naungan yang berbeda pada tiga kultivar kacang tanah terhadap pertumbuhan dan hasil, serta mendapatkan kultivar kacang tanah yang toleran terhadap naungan. Percobaan pot dilakukan di kebun percobaan Fakultas Pertanian Universitas Winaya Mukti dari bulan Juli sampai dengan Oktober 2016. Perlakuan percobaan adalah perbedaan naungan (tanpa naungan, naungan $50 \%, 65 \%$ dan $75 \%$ ) selama siklus hidup tiga kultivar tanaman kacang tanah (Tuban, Jepara dan Bima). Hasil percobaan menunjukkan bahwa naungan memengaruhi jumlah daun trifoliat, jumlah cabang, bobot kering tanaman, komponen hasil (jumlah polong, jumlah polong isi, dan jumlah biji), bobot kering polong dan bobot kering biji per tanaman. Kultivar memberikan efek yang sama terhadap pertumbuhan dan hasil per tanaman. Berdasarkan analisis Stress Tolerance Index (STI) terhadap bobot kering per tanaman, hanya kultivar Tuban yang toleran pada naungan $65 \%$. Semua kultivar peka terhadap naungan $75 \%$.

Kata kunci : efek naungan, kultivar kacang tanah, toleransi naungan

Cyte this as: Noertjahyani, Akbar, C., Komariah, A. \& Mulyana, H. (2020). Shade effect on growth, yield, and shade tolerance of three peanut cultivars. Jurnal Agro, 7(1), 102-111. 


\section{INTRODUCTION}

A plant naturally needs light for its growth especially for photosynthesis process. Light is one of important factors for plant's growth in the ecosystem and an environment factor which affects the growth, morphology, physiology, and biochemistry of the plant (Kwon \& Woo, 2016). Therefore, the light highly affects the growth and yield of a plant. In other words, light is the delimiter factor for growth and yield of a plant.

The plant responses due to the light stress are various, because plants' light requirements are different depending on the plant species / genotypes and environment. There are two methods of plants in responding less favorable conditions; abolishing or avoiding the stress and being tolerance towards stress. The response of plant in shaded environment is determined by the plant tolerance towards reduction of light intensity. The plants which are tolerance to shading or low light intensity are highly needed to be use $d$ as a plant component on intercropping system also planted under the tree stands on intercultural system. Intercropping and intercultural systems are the efforts for land use efficiency due to the decreasing of agricultural land in Indonesia because of land functional shift. Somehow, wrong selection of plant types or plant cultivar on interculture system will cause non optimal yield.

Peanut is one component of intercultural plants or alternative of intercropping plants which is socially and economically beneficial moreover it is usefull for fertilizing the soil. This plant requires enough sunlight, and based on its photosynthesis type, it belongs to C3 plants group which is responsive to shade.

Plant response as the effect of environmental factors can be seen on the performance. The plants try to respond to its special needs during its life cycle, if the environment factor does not support. This kind of response can effect on a morphological, physiological, or anatomical character. Although the genotype is the same, in a different environment the re can cause a different performance (Suparman \& Abdurrahman, 2003). A previous research showed that shade can decrease the plant yield significant at nuts, like soybean, peanut, and green bean (Susanto \& Sundari, 2011; Sundari \& Susanto, 2015).

The usage of superior variety with higher productivity has been done in efforts to increase production. Whether, the superior variety/cultivar tolerance will constantly give high yield if planted under shaded place is interesting to find out. Physiologically, the plant said as shade tolerance if it can survive under minimum light condition (Valladares \& Niinemets, 2008). The tolerance level of plant species/ variety/ cultivars is various and can be known through Stress Tolerance Index (STI) on percentage of decreased observed character.

This research was taken with the purpose to study the shade effect towards growth and yield of three peanut cultivars and to determine which peanut cultivar that is tolerant of shade. The three cultivars are superior cultivars that have long been released but are still widely planted, have the same harvest age, have a fairly high average yield (1.7-2 t ha ${ }^{-1}$ of dry seeds yield) 
(Kasno \& Harnowo, 2014). The result of this research is expected that it becomes a more efficient method to prevent the decreasing of plant productivity on the shaded environment.

\section{MATERIALS AND METHOD}

This research was a verificative experiment by using pot experiment. This study was carried out at the Research Station of Agriculture Faculty Universitas Winaya Mukti with altitude of $820 \mathrm{~m}$ above sea level. The experiment was done since June until September 2016. Three peanut cultivars, namely Tuban, Jerapah, and Bima, were planted under different shade le vels; without shade or full light intensity; shad ed by $50 \%, 65 \%$, and $75 \%$ levels during the plants' life cycle. Shade arrangement used paranet that was installed before planting, and reached $1.2 \mathrm{~m}$ of height. The placement of treatments used Split Plot Design, where the shade as main plot and variety as subplot. Each treatment was repeated three times.

The pot was filled by 8 kilos of soil, then added with chicken manure at the dose of 20 tons per ha ( $80 \mathrm{~g}$ per pot) by mixing it evenly in each growing media. Two grains of peanut seeds were planted per pot and one plant was maintained until the harvest. The fertilization of $\mathrm{N}, \mathrm{P}$, and $\mathrm{K}$ was given on 15 days after the planting with the dose of 50 kilos ha-1 of Urea ( $46 \% \mathrm{~N}), 60$ kilos ha $^{-1}$ of SP-36 $\left(36 \% \mathrm{P}_{2} \mathrm{O}_{5}\right)$, and 50 kilos ha-1 of $\mathrm{KCl}$ $\left(60 \% \mathrm{~K}_{2} \mathrm{O}\right)$.

Growth, yield components, pods dry weight, and seed dry weight per plant as the tolerance level of shade on three peanut cultivars were observed as plant responses due to shade. Variation of treatments were analyzed by using $F$ test with significant level of $5 \%$ and LSD test of $5 \%$ significant level was used to examine the differences among treatments. The determination of tolerance level on shade for each cultivar was based on Stress Tolerance Index value gained by formula: $\mathrm{STI}=\left[(\mathrm{Yp})(\mathrm{Ys}) /(\overline{\mathrm{Y}} \mathrm{p})^{2}\right]$ (Fernandez, $1992 \mathrm{cit}$. Komariah, et al., 2017).

\section{RESULTS AND DISCUSSION}

Plants will give response if the growth factors are limited. The shade will cause light accepted by the plants reduced, not only the quantity but also the quality. According to analysis of variance, there was no interaction effect between shade and variety, toward growth and yield of the tested peanut. This might be happened because the three cultivars used genetically belong to the same type of peanuts, which is Spanish, so they have similarities on many plant characters. Most of superior cultivars that have been released and widely planted in Indonesia include the Spanish type, fastigiata spp with some of the main characteristics are same (Dwi Utomo et al., 2005; Kasno \& Harnowo, 2014; Sumarno, 2015)

Individually, shade increased plants height at each observation time. Plants height on unshaded was lower than shade $d$ plants (Table 1). On unshaded plants, auxin activity is inhibited by the light, but on the shaded plants the activity is higher (Yang et al., 2018), so that there is increasing on cleavage and stem cells extension. The shaded plants were said to have etiolation. As the result, the shaded plants height was taller than unshaded ones. The same thing happens on results research of Dalmolin et al. (2012), and Ratri et al., (2015) that 
shading significantly increases plants height. Meanwhile, cultivar treatment gave different effects toward plants height at 14 DAP, 28 DAP and 42 DAP, but it was relatively the same on the last observation (56 DAP).

The number of unshaded peanut leaves was more than the shaded plants (Table 2). The more increasing the shade (light intensity decreases), the fewer numbers of the leaves. Seventy five percent shade caused the fewest numbers of trifoliate leaves on every observation time Similar results occur in tumeric plants and Arabidopsis, where the number of leaves decreases due to shading (Cookson \& Granier, 2006; Ratri et al., 2015). Haryanti (2010) assumed that shade plants have small roots, fewer numbers of roots and thinner cell walls as reducing effect of photosynthesis product to roots. This causes the absorption of nutrients by the root is decreased and will inhibit leaf growth including leaf formation the le ad to fewer number of leaves.
On Table 2 is seen that cultivar generated real effects on the leaves number per plant on 14, 28 and 42 DAP observation times. Tuban cultivar had the most leaves number, followed by Jerapah and Bima. However, in the end of observation the leaves number showed unreal differences for the three peanuts cultivars.

As well as the plant height and leave numbers, yield components were also more affected by the shade than the cultivar. The shading caused decreasing on branch number, plant dry weight and other yield components i.e. number of pods and dry weight of filled pods per plant. Unshaded peanuts had the highest number of branch and dry weight of stover, and was really different from the shaded plants (Table 3). The more shading level caused lower light intensity received by the plants, it led a decreasing of dry weight and number of branches, pods, and filled pods perplant.

Table 1. Individual effect of shade and peanut cultivar on plant height

\begin{tabular}{|c|c|c|c|c|c|c|c|c|}
\hline \multirow{2}{*}{ Treatments } & \multicolumn{8}{|c|}{ Average of plant height $(\mathrm{cm})$} \\
\hline & \multicolumn{2}{|c|}{14 DAP } & \multicolumn{2}{|c|}{28 DAP } & \multicolumn{2}{|c|}{42 DAP } & \multicolumn{2}{|c|}{56 DAP } \\
\hline \multicolumn{8}{|l|}{ Shade: } & \\
\hline Unshaded & 10.08 & a & 16.48 & $\mathrm{a}$ & 27.18 & $\mathrm{a}$ & 36.62 & $a$ \\
\hline $50 \%$ shade & 11.51 & $b$ & 17.82 & $b$ & 29.12 & $b$ & 41.30 & $b$ \\
\hline $65 \%$ shade & 11.64 & $b$ & 17.10 & $a b$ & 25.48 & a & 38.69 & a \\
\hline $75 \%$ shade & 12.71 & c & 21.93 & $c$ & 29.56 & b & 38.77 & a \\
\hline Lsd.05 $_{.05}$ & 0.60 & & 1.09 & & 1.70 & & 2.51 & \\
\hline \multicolumn{9}{|l|}{ Peanut cultivar: } \\
\hline Tuban & 11.00 & a & 17.30 & a & 26.62 & a & 37.76 & a \\
\hline Jerapah & 11.53 & $a b$ & 18.31 & $b$ & 27.85 & $a b$ & 39.29 & a \\
\hline Bima & 11.93 & $\mathrm{~b}$ & 19.39 & c & 29.03 & $\mathrm{~b}$ & 39.49 & $\mathrm{a}$ \\
\hline Lsd. $_{.05}$ & 0.59 & & 0.84 & & 1.80 & & 2.39 & \\
\hline
\end{tabular}

Remarks: Numbers followed by same letter are not significantly different based on Least Significant Difference (LSD) Test at $5 \%$ level

Light is one of environmental factors which is highly needed in the process of photosynthesis. On the more increasing shade, light intensity received by the plants 
will be lower, the process of photosynthesis will be reduced so that the stored photosynthesis result is lesser. This availability of photosynthate may limit the growth of branch and the number of leaves, so that the dry weight of stover becomes low. According to the research of Adelusi \& Aileme (2006) showed that peanut index leaf area and dry weight were both significantly reduced by shading. Other researcher (Hemon, et al., 2018) shows that decreasing of dry stover weight in mutant peanut genotypes reached $48.5 \%-72.5 \%$ due to shading. Also, at some cultivars of green gram showe d that significantly reduction in total dry weight and thinner leaf thickness due to shading (Araki, et al., 2014).

Table 2. Individual effect of shade and peanut cultivar on number of leaves

\begin{tabular}{|c|c|c|c|c|c|c|c|c|}
\hline \multirow{2}{*}{ Treatments } & \multicolumn{8}{|c|}{ Number of leaves } \\
\hline & \multicolumn{2}{|c|}{14 DAP } & \multicolumn{2}{|c|}{28 DAP } & \multicolumn{2}{|c|}{42 DAP } & \multicolumn{2}{|c|}{$56 \mathrm{DAP}$} \\
\hline \multicolumn{9}{|l|}{ Shade: } \\
\hline Unshaded & 4.78 & d & 17.69 & $d$ & 35.14 & $d$ & 53.31 & c \\
\hline $50 \%$ shade & 3.97 & c & 15.39 & c & 30.39 & c & 49.33 & c \\
\hline $65 \%$ shade & 3.64 & $b$ & 12.53 & $b$ & 25.33 & $b$ & 40.64 & $b$ \\
\hline $75 \%$ shade & 3.00 & a & 10.56 & $a$ & 20.33 & a & 30.89 & $\mathrm{a}$ \\
\hline Lsd.05 $_{.0}$ & 0.12 & & 1.28 & & 3.36 & & 5.90 & \\
\hline \multicolumn{9}{|l|}{ Peanut cultivar: } \\
\hline Tuban & 3.83 & b & 14.31 & b & 28.27 & $a b$ & 45.06 & a \\
\hline Jerapah & 4.58 & c & 15.19 & $b$ & 29.02 & $b$ & 42.79 & a \\
\hline Bima & 3.13 & a & 12.63 & $a$ & 26.10 & a & 42.77 & a \\
\hline Lsd.05 $_{.0}$ & 0.15 & & 1.27 & & 2.91 & & 2.49 & \\
\hline
\end{tabular}

Remarks: Numbers followed by same letter are not significantly different based on Least Significant Difference (LSD) Test at $5 \%$ level

The main cause of decreasing dry weight due to shading is the lower photosynthesis process which depends on receveid light. Some enzymes of photosynthesis process, i.e phosphoriboisomerase, phosphoribulokinase, ribulose-1,5-diPcarboxylase, need enough light for activation. If the light is not sufficient, the enzymes will be deactivated until the fixation of $\mathrm{CO}_{2}$ decreases and the photosynthesis process is hampered (Shao, et al., 2014; Kwon \& Woo, 2016).

Branch is included to vegetative part of plant where the leaves stick on. The pods and filled pods number per plant dropped following the more increasing of shading, as it happened to the branch numbers
(Table 3). According of the research of Gultom (2008) which shows that was a positive correlation between branch numbers towards pods and filled pods numbers per plant. On this research, it can be pressumed that when the branch number increased, leaves number also elevated, led to the increase of photosynthesis process. Therefor pod and filled pod would get more assimilate to grow.

Cultivar affected on branch, pods, and filled pods number per plant variously, except on plant dry weight. Pods and filled pods number per plant of Tuban and Jerapah cultivars were more than Bima cultivar. They are relatively resistant and 
tolerant to major diseases of peanuts, meanwhile Bima cultivar has a susceptible on rust and moderate-tolerant on wilt diseases (Kasno \& Hernowo, 2014). This is likely to cause differences in responses among cultivars.

Table 3. Individual effect of shade and peanut cultivar on component of vegetative growth and pods yield

\begin{tabular}{|c|c|c|c|c|}
\hline Treatments & $\begin{array}{c}\text { Number of } \\
\text { branches }\end{array}$ & $\begin{array}{l}\text { Plant dry } \\
\text { weight (g) }\end{array}$ & $\begin{array}{c}\text { Number of } \\
\text { pods per plant }\end{array}$ & $\begin{array}{c}\text { Number of filled pods } \\
\text { perplant }\end{array}$ \\
\hline \multicolumn{5}{|l|}{ Shade: } \\
\hline Unshaded & $8.67 d$ & $83.52 d$ & $38.08 \mathrm{c}$ & $34.22 \mathrm{~d}$ \\
\hline $50 \%$ shade & $7.92 \mathrm{c}$ & $67.85 \mathrm{C}$ & $24.83 \mathrm{~b}$ & $22.92 \mathrm{C}$ \\
\hline $65 \%$ shade & $7.00 \mathrm{~b}$ & $54.74 \quad b$ & $20.86 \quad b$ & $18.61 \quad b$ \\
\hline $75 \%$ shade & $4.84 \quad \mathrm{a}$ & $30.81 \quad a$ & $11.03 \quad \mathrm{a}$ & $9.17 \quad \mathrm{a}$ \\
\hline Lsd.05 & 0.20 & 9.78 & 5.72 & 1.63 \\
\hline \multicolumn{5}{|l|}{ Peanut cultivar: } \\
\hline Tuban & $6.96 \quad a$ & $61.44 \quad a$ & $25.15 \quad b$ & $22.92 \quad b$ \\
\hline Jerapah & $7.33 \quad b$ & $57.95 \quad a$ & $26.75 b$ & $23.71 \quad b$ \\
\hline Bima & $7.03 \quad a$ & $58.30 \quad a$ & $19.21 \mathrm{a}$ & $17.06 \mathrm{a}$ \\
\hline Lsd.05 & 0.15 & 8.03 & 3.54 & 2.17 \\
\hline
\end{tabular}

Remarks: Numbers followed by same letter are not significantly different based on Least Significant Difference (LSD) Test at 5\% level

Shade effects on pods weight and seeds yield are listed on Table 4. The higher the shade level (light intensity decreases), the lowerfresh pods weight, dry pods weight, and seeds yield per plant (seeds number and weight). According to the research of Susanto \& Sundari (2011) which shows that $50 \%$ shade reduced the number of pods and seed weight compared to those in unshaded soybean. Podding is a very sensitive phase towards shading. High pods weight is supported by lots number of pods because pods and filled pods number are positively correlated with filled pods weight (Sundari, 2016). Consequently, the highest dry pods weight was on unshaded plants and the lowest was on the plants with $75 \%$ shaded.

Table 4. Individual effect of shade and peanut cultivar on pods and seed yield

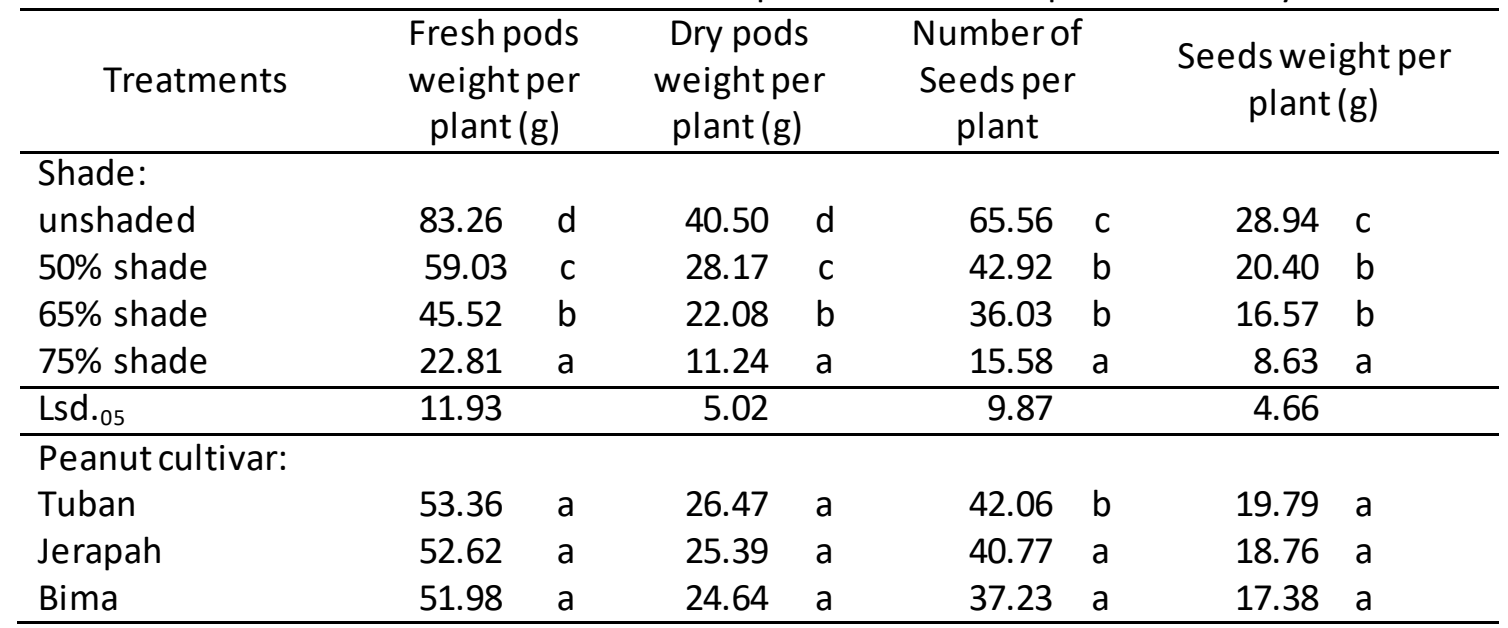




\begin{tabular}{lcccc}
\hline Lsd. $_{05}$ & 7.89 & 3.92 & 4.74 & 2.78 \\
\hline Remarks: Numbers followed by same letter are not significantly different based on Least Significant
\end{tabular}
Difference (LSD) Test at 5\% level

The shade, besides affected the growth and yield component, also affected peanut seeds yield. The higher level of shade, the lower seeds yield. The lowest dry seeds yield was on $75 \%$ level of shade. Low seeds yield due to shading during plant life cycle was caused by leaves numbers and branch numbers (as a source) that became fewer, lower photosynthesis capacity, and inadequate photosynthesis to raise yield component (pods number and weight) which finally led to low seeds yield of peanut. This is in line with the opinion of Kwon \& Woo (2016) that shaded plants will have thinner leaves, decreased palisade parenchym, lower leaf area, lower photosynthesis and lastly could affected on yield components.

The highest unshaded seeds yield was also supported by the pods number and pods weight, also the most seeds number.
Those yield components were positively correlated with the yield. Shade effects on the decrease of peanuts seeds yield is seen on Figure 1. The highest decrease of dry seeds yield (>70\%) was found on $75 \%$ of shade, followed by $65 \%$, and $50 \%$ of shade for each $>40 \%$ and $<5 \%$, respectively. Research result of Chen et al. (2019), rice yield decreased under shade $15 \%-20 \%$ compared to under sunny day. The decrease of yield due to shading also occurs to beans and corn. Research result of Sundari \& Susanto (2015) showed that $75 \%$ of shade gives lower soybean yield than $50 \%$ and $25 \%$ of shade, for each decrease $30.01 \%$ and $65.21 \%$. Corn's Yield compared with unshaded reduced by shade (Li et al., 2005). Shaded on two corn inbred with the intensity of $50 \%$ and $90 \%$ successively decrease $67.5 \%, 79 \%$, and $82.9 \%, 86.7 \%$ of yield (Zhang et al., 2006).

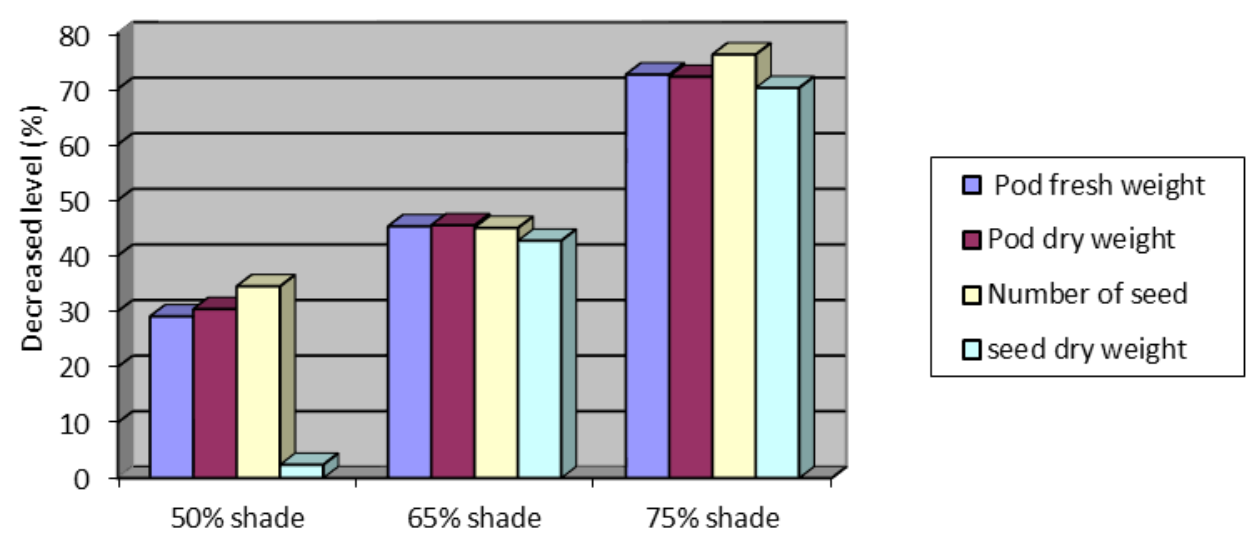

Figure 1. Decreased level of pods and seed yield toward unshaded peanut

Research result on the level tolerance of peanut cultivar on shade, which is declared through STI value listed on Table 5. Tuban, Jerapah, and Bima cultivars are still tolerant of $50 \%$ of shade. It means that if three peanut cultivars are planted und er
$50 \%$ shade ( $50 \%$ of light intensity), they will still give good yield. However, if $75 \%$ of shade ( $25 \%$ of light intensity), the three cultivars gave terrible yield and it proved by the high decline percentage of dry seeds yield ( $>70 \%)$. Out of three peanut cultivars 
used in the experiment, only Tuban cultivar that was tolerant of $65 \%$ of shade with 0.5959 of STI value (tolerant). This means that the Tuban variety on $65 \%$ shade still gave better growth and yield than the Jerapah and Bima varieties.

Plant tolerance towards low-light stress is a plant genetic trait. The low-light tolerance of plants is a complex trait, and at the cucumber plant the trait is controlled by several major genes and a mini-polygene base on the classical analysis method and QTL (quantitative trait locus) (Li, et al., 2015). Traits that are controlled by polygenic genes are strongly influenced by the environment.

Table 5. Stress Tolerance Index (STI) values at three peanut cultivars in different shades

\begin{tabular}{clll}
\hline \multirow{2}{*}{ Shaded } & \multicolumn{3}{c}{ STI value } \\
\cline { 2 - 4 } & \multicolumn{1}{c}{ Tuban } & \multicolumn{1}{c}{ Jerapah } & \multicolumn{1}{c}{ Bima } \\
\hline $50 \%$ & 0.7496 (tolerant) & 0.6655 (tolerant) & 0.6715 (tolerant) \\
$65 \%$ & 0.5959 (tolerant) & 0.5647 (moderate) & 0.4743 (moderate) \\
$75 \%$ & 0.2692 (susceptible) & 0.2728 (susceptible) & 0.2907 (susceptible) \\
\hline
\end{tabular}

\section{CONCLUSION}

Shade independently more affected on plant growth and yield compared to cultivar. Shade escalated plant height but significantly reduced branch numbers, leaves numbers, yield components, and peanut yield. Seventy five percent of shade showed the most decline of dry seed yield, and the three cultivars included to intolerant category at this shade level. Tuban and Jerapah cultivars gave higher dry seeds weight per plant than Bima. Based on calculation of STI value, only Tuban cultivar that was tolerant of $65 \%$ of shading. All cultivars were sensitive on $75 \%$ shade.

\section{REFERENCES}

Adelusi, A.A. \& J.D. Aileme (2006). Effect of light and nutrient stress on some growth parameters of cowpea (Vigna unguiculata (L.) Walp. Res. J. Bot. 1(2):95-103. DOI 10.3923/rjb.2006.95. 103

Araki, T., Thay T. Oo \& F. Kubota (2014). Effects of shading on growth and photosynthetic potential of greengram (Vigna radiata (L.) Wilczek) cultivars. Environ. Control Biol. 52(4): 227-231. DOI 10.2525/ecb.52.227

Chen, H., Qiu-Ping Li, Yu-Ling Zeng, Fei Deng, \& Wan-Jun Ren, (2019). Effect of different shading materials on grain yield and quality of rice. Scientific Report 9: 9992-10000 https://doi.org/ 10.1038/s41598-019-46437-9

Cookson, S.J. \& C. Granier, (2006). A dynamic analysis of the shade-induced plasticity in Arabidopsis thaliana rosette leaf development reveals new components of the shade-adaptative response. Annals Bot., 97(3):443-452. DOI 10.1093/aob/mcj047

Dalmolin, Â. C., H.J. Dalmagro, F. de Almei-da Lobo, M. Z. Antunes Junior, C.E. Rogríguez Ortíz, \& G.L.Vourlitis, (2012). Effects of flooding and shading on growth and gas exchange of Vochysia divergens Pohl (Vochysiaceae) of invasive species in the Brazilian Pantanal. Braz. J. Plant Phys. 24(2):75-84. DOI 10.1590/S1677-04202012000200001

Dwi Utomo, S., M. Imam Surya, Ansori, Hasriadi Mat Akin, \& Tjipto Roso 
Basoeki, (2005). Pemanfaatan subspecies hypogaea dalam perakitan varietas unggul kacang tanah (Arachis hypogaea L.) berbiji besar dan berpolong banyak di Indonesia. IImu Pertanian, 12(2): 84-93.

Gultom, T. (2008). Analisis korelasi dan koefisien lintas sifat agronomi terhadap hasil tanaman kacang tanah. (Thesis) $\quad 127$. http://repository.usu.ac.id/bitstream/handle/123456789/3882/0400 7960. pdf?sequence $=1 \&$ isAllowed=y

Haryanti, S. (2010). Pengaruh naungan yang berbeda terhadap jumlah stomata dan ukuran porus stomata daun Zephyranthes Rosea Lindl. Buletin Anatomidan Fisiologi, 18(1):4148. DOI: 10.14710/baf. v18i1.2617

Hemon, A. Farid, Ida Wahyuni, Kisman, Sumarjan, \& H. Abdurrachman, (2018). Performance of peanut mutant genotypes grown under drought and shade stress. Pros. Sem. Nas. Masy. Biodiversity Indonesia, 4(2):202-207. https://doi.org/10.13057/psnmbi/m04 0218.

Kasno, A \& Didik Harnowo, (2014). Karakteristik vaietas unggul kacang tanah dan adopsinya oleh petani. IPTEK Tanaman Pangan, 9(1): 13-23.

Komariah, A., E.C. Waloeyo, \& O. Hidayat. (2017). Pengaruh penggunaan naungan terhadap pertumbuhan dan hasil dua varietas tanaman kacang merah (Phaseolus vulgaris L). J. Paspalum, 5(1):33-42. DOI: 10.35138/paspalum. v5i1.35

Kwon, M. Y. \& Su Young Woo, (2016). Plants responses to drought and shade environments. Afr. J. Biotech. 15(2): 29-31. DOI 10.5897/ajb2015.15017
Li, C.-Feng, L.-M. Luan, F. yin, Q. Wang, \& Y.-L. Zhao, (2005). Effects of light stress at different stages on the growth and yield of different maize genotypes (Zea mays L.). Acta Ecologica Sinica, 25 (4): 824-830.

Li, D. D.,Qin, Z. W.. Lian, H..Yu, G. B., Sheng, Y. Y. \& Liu, F. (2015). Inheritance and quantitative trait locus analysis of low light tolerance in cucumber (Cucumis sativus L.) Genetics and Molecular Res. 14(3): 10609-10918.DOI 10.4238/2015. September.9.2

Ratri, A. D. Y. S., B. Pujiasmanto. \& A.Yunus, (2015). Efek naungan dan cekaman air terhadap pertumbuhan dan hasil kunyit Di Kismantoro, Wonogiri. Caraka Tani: J.Sustain. Agric., 30(1): 1-6. DOI 10.20961/ carakatani. v30i1.11826

Shao, Q., H. Wang, H. Guo, A. Zhou, Y. Huang, Y. Sun \& M. Li. (2014). Effects of shade treatments on photosynthetic characteristics, chloroplast ultrastructure, and physiology of Anoectochilus roxburghii. PLOS ONE, 9(2): 10 p. DOI 10.1371/journal.pone.0085996

Sumarno, (2015). Status kacang tanah di Indonesia. Monograf Balitkabi, 13: 2939. http://balitkabi.litbang. pertanian. go.id/wp-content/uploads/2017/01/3. monograf

Sundari, T. \& G.W.A. Susanto (2015). Pertumbuhan dan hasil biji genotipe kedelai di berbagai intensitas naungan. Penelitian Pertanian Tanaman Pangan. 34(3): 203-217. DOI http://dx.doi.org /10.21082/jpptp.v34n3

Sundari, T., (2016). Penampilan galur-galur kedelai toleran naungan di dua lingkungan. Bul. Palawija, 14(2): 6370. http://balitkabi.litbang.pertanian. go. id/ wp-content/uploads/2017/11/ 14_23_Titik_63-70.pdf 
Suparman \& Abdurrahman, (2003).

Teknik pengujian galur kacang tanah toleran naungan di bawah pohon kelapa. Bul. Teknik Pertanian, 8 (2): 76-79. Eprints.unram.ac.id

Susanto, G. W. A. \& T. Sundari, (2011). Perubahan karakter agronomi Aksesi plasma nutfah kedelai di lingkungan ternaungi .J. Agron. Indonesia, 39(1):16. https://journal.ipb.ac.id/index.php/ jurnalagronomi/article/view/13180/99 25

Valladares, F. \& U. Niinemets, (2008). Shade tolerance, a key plant feature of complex nature and consequences. Annu. Rev. Ecol. Evol. Syst., 39(1):237-
257. DOI 10.1146/annurev. ecolsys. 39.110707.173506

Yang, F., X. Wu, Y.Cheng, Q. Liu, L.Feng, J. Chen, Z.Wang, X. Wang, T. Yong, \& W. Liu. (2018). Auxin-to-gibberellin ratio as a signal for light intensity and quality in regulating soybean growth and matter partitioning. Front. Plant Sci. 9(Januari) article 56: 13 p. DOI 10.3389/fpls. 2018.00056

Zhang J., S. Dong S, Wang K, Hu C, Liu P. (2006). Effects of shading on the growth, development and grain yield of summer maize. (Abstract). https:// www.ncbi.nlm.nih.gov/pubmed/16836 097 